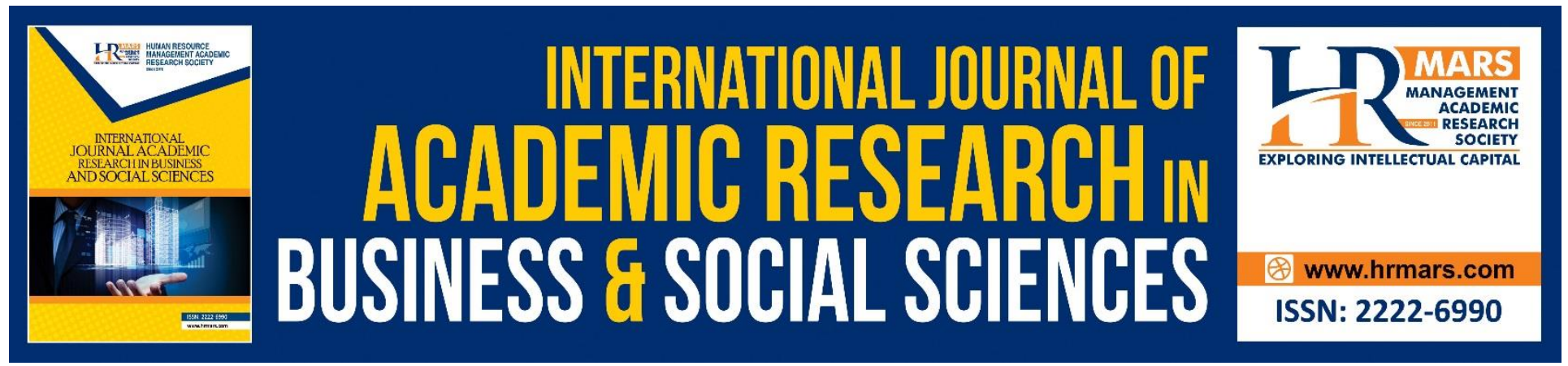

\title{
Exploring Inclusive Education Strategy for Optimization of Learning Capacity and Access to Health Information among Children with Disabilities (CWD) in Nigeria
}

Nwankwo, Ignatius Uche and Nnatu, Stella Obioma

To Link this Article: http://dx.doi.org/10.6007/IJARBSS/v8-i9/4687

DOI: $10.6007 /$ IJARBSS/v8-i9/4687

Received: 11 August 2018, Revised: 17 Sept 2018, Accepted: 29 Sept 2018

Published Online: 12 October 2018

In-Text Citation: (Nwankwo \& Nnatu, 2018)

To Cite this Article: Nwankwo, I. U., \& Nnatu, S. O. (2018). Exploring Inclusive Education Strategy for Optimization of Learning Capacity and Access to Health Information among Children with Disabilities (CWD) in Nigeria. International Journal of Academic Research in Business and Social Sciences, 8(9), 1147-1163.

Copyright: (C) 2018 The Author(s)

Published by Human Resource Management Academic Research Society (www.hrmars.com)

This article is published under the Creative Commons Attribution (CC BY 4.0) license. Anyone may reproduce, distribute, translate and create derivative works of this article (for both commercial and non-commercial purposes), subject to full attribution to the original publication and authors. The full terms of this license may be seen at: http://creativecommons.org/licences/by/4.0/legalcode

Vol. 8, No. 9, September 2018, Pg. 1147 - 1163

Full Terms \& Conditions of access and use can be found at http://hrmars.com/index.php/pages/detail/publication-ethics 


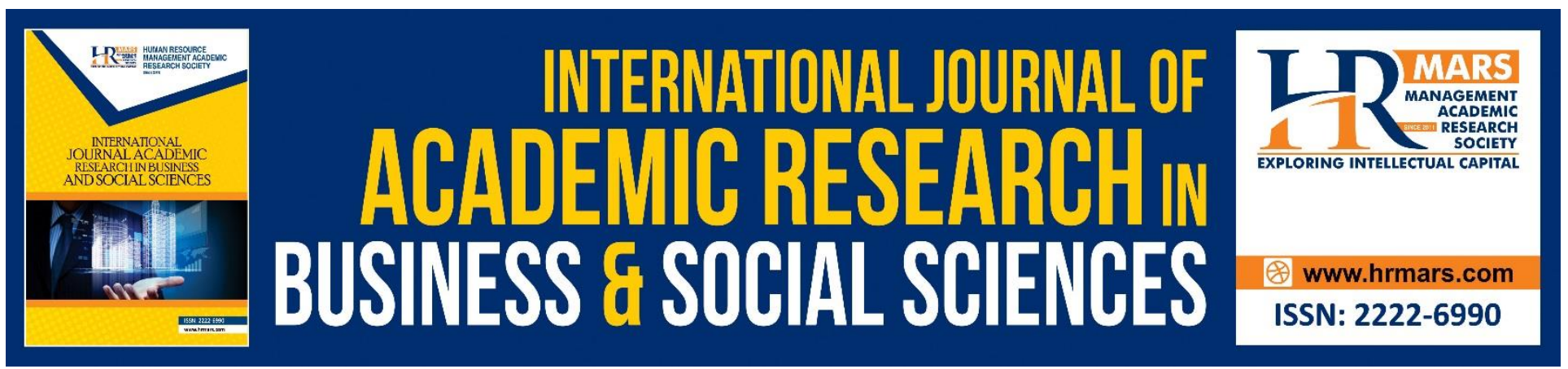

\title{
Exploring Inclusive Education Strategy for Optimization of Learning Capacity and Access to Health Information among Children with Disabilities (CWD) in Nigeria
}

\author{
Nwankwo, Ignatius Uche and Nnatu, Stella Obioma \\ Department of Sociology/Anthropology, Nnamdi Azikiwe University, Awka, Anambra State, Nigeria \\ Email: iunwankwo@yahoo.com
}

\begin{abstract}
This review paper examined inclusive education for the disabled in Nigeria with a view to ascertaining level of implementation, successes and challenges being encountered. Secondary data were relied upon while symbolic interactionism theory was adopted as theoretical framework. The study pointed out that Inclusive Education provides adequate educational support for all pupils and promotes successful learning as well as access to health information. However, teachers' perception about disabled children often affects their academic performance. The fact that disabled people are stigmatized by the public was also frowned at and Inclusive education was strongly recommended since it breaks down barriers and prejudices. Inclusive education benefits the disabled people and the entire society. The study recommended that inclusive education should be adequately financed by the government, schools and other international organizations. Parental education programmes should be provided. Inclusive learning environment should be created through engagement of teachers associations and other stakeholders with programmes to increase their understanding and knowledge of disability. Segregation within schools should be ended by monitoring schools on a regular basis.
\end{abstract}

Keywords: Children with Disabilities, Educational Support, Health Information, Inclusive Education, Stigmatization

\section{Introduction}

Education refers to the act of impacting or gaining knowledge, and a level of intellectual maturity. It is also the process of acquiring particular skill in a formal institution of learning. According to Egbue (2010), education is a process whereby culture, knowledge and skills are transferred to an individual for the improvement of entire his well being which can be done through socialization. As an important tool for development, education is relevant to both the able bodied and persons with physical 
INTERNATIONAL JOURNAL OF ACADEMIC RESEARCH IN BUSINESS AND SOCIAL SCIENCES Vol. 8, No. 9, Sept. 2018, E-ISSN: 2222-6990 @ 2018 HRMARS

challenges or disabilities. Thus, education is not simply about making schools available for those who are already able to access them. It is about being proactive in identifying the barriers and obstacles learners encounter in attempting to access opportunities for quality education, as well as in removing those barriers and obstacles that lead to exclusion (UNESCO, 2012).

The word 'disabilities' according to the World Health Organization (WHO) constitute an umbrella term, covering impairments, activity limitations, and participation restrictions. It is also the consequence of an impairment that may be physical, cognitive, mental, sensory, emotional, developmental, or some combination of these.

Because of the need to ensure that all members of every society have access to quality education, the strategy of inclusive education is being strongly canvassed across the globe. Of similar significance is the provision of adequate educational support to meet the needs of all categories of learners, including those with disabilities. While educational support has to do with the adequate numbers of personnel; adequate staff development and technical assistant; inclusive education on the other hand means that schools should accommodate all children regardless of their physical, intellectual, social, emotional, linguistic or other conditions.

Thus successful inclusive education means creating learning environments that respond to the needs of all learners to achieve the greatest impact on social, emotional, physical and cognitive development. Ultimately, inclusive education is an attempt to ensure optimal academic performance and learning on the part of all learners (with or without disabilities). In addition to optimized learning capacity, inclusive education could also stimulate access to health information especially among persons and children with disability. This is because it equips such persons with the ability to read and write all types of information through the improved academic standard.

According to Dictionary of Common Special Educational Terms (2014), academic performance may be defined as a student's level of academic achievement when measured against the general curriculum. It also refers to how students deals with or accomplish different tasks given to them by their teachers. Academic performance is the ability to study and remember facts and being able to communicate your knowledge verbally or on paper.

Scott (2011) noted that although students learn many things in the classroom, the primary objective is for students to learn academic contents of outlined courses. In order for teachers to know if students are achieving this academic knowledge, they generally are required to not only assess students, knowledge in some way, but eventually summarize that assessment into a letter or numerical grade. The assessment then becomes the academic performance of the student.

Centre for Disease Control (2010) documented those academic outcomes can be grouped into three categories namely academic achievement (such as grades, text scores); academic behavior (such as attendance, on task behavior) and cognitive skills (such as attention, concentration, memory). This goes to show that a student with good academic performance must have excelled in the three variables mentioned above. Scott (2011) in his own view argued that academic performance can be measured through grades (tests and assignments); extracurricular activities/students engagement in sports, and so on) and behavior (students obedience or violation to school rules and regulations).

According to Cooley (2002) several factors such as parental style, method of teaching, parental socio economic status and so on have been noted over the years as facilitating students' academic performance. However, Airasian (2000) argued that technological gadgets will have the greatest 
impact on students learning when integrated into the curriculum. This will help to achieve clear measurable educational objectives. He further opined that technological facilities such as the internet can broaden the range of students' choices for learning.

Many research studies have found that the performance of students without disabilities is not compromised by the presence of students with disabilities in their classrooms. When schools embrace inclusive education as a whole school reform effort, they find that the achievement of all students improves.

In concluding, in 2015, the Nigerian government declared it had reached universal enrollment in primary education and achieved the United Nations Millennium Development Goal on education, requiring it to ensure that all girls and boys were in school and had completed a full course of primary education by that year.

The Tomlinson Report was presented by the Further Education Fund Council (learning difficulties and/or disabilities committee). The committee has pointed out several facts which the government needed to pay immediate notice. For instance, the committee noted that legislation governing further education does not explicitly establish rights for disabled students nor outlaw discrimination. The needs of this group of learners would be met if new content was introduced to the learning practice (Bethan, 2005).

\section{Objectives of the Study}

The overall objective of this review paper is to examine the implementation, problems and successes recorded in the area of inclusive education in Nigeria. The specific objectives were:

i. To review the meaning, rationale for adoption and benefits derivable from inclusive education in Nigeria

ii. To account for the stakeholders of inclusive education in Nigeria and the categories of children that require it

iii. To review disability related problems encountered in schools and Nigerian society at large

iv. To make a case for right to education, access to health information and educational support for all children in Nigeria

\section{Methodology}

The study location or focus is on Nigeria. As a review paper, this study relied principally on secondary sources (books, journals, official publications of government and international organizations etc.) Content analysis technique was used to decode or interpret the content of such documents. In several cases, excerpts were also drawn from the documents and quoted to support arguments raised in the paper.

\section{Theoretical Framework: Symbolic Interactionism}

The American philosopher George Herbert Mead (1863-1937) is widely regarded as the founder of this perspective (Haralambos, 2004). Scholars like Charles Horton Cooley, Roberton Ezra, and William James, Erving Goffman and Herbert Bulmer played pivotal roles in the development of symbolic interactionism. 
Symbolic interactionism is a framework for viewing human being as living in a world of meaningful objects. These objects include things, actions, other people relationships and even symbol (Heslin, 1972). Discrimination, like all human behavior is symbolic. Non disable and disabled use symbols and exist in a world of meaning created by those symbols. Discrimination against the disabled is associated with a variety of behavioral activities each with different meanings including the feeling of inferiority complex, dehumanization, inhumane and psychological sense of inadequacy also the restriction in love, relationship, education and marriage, between the disabled and non-disabled and any other persons causes a serious psychological problem. The disabled discrimination is very pronounced in the area of education and marriage. Non- disable cannot marry disabled (Igwe, 2008). The importance of meaning is reflected in Thomas's (1939) famous dictum. If situations are defined as real, they are real in their consequences. The definition of the situation emphasizes that people act in situations on the basis of how they are defined. For example, if a teacher defines a student as a slow learner (based on inaccurate information), his or her discriminatory behavior (e.g. less attention and lower expectations) may have a negative effect on the students' intellectual development, resulting in a self-fulfilling prophecy. This process, in combination with interactionist ideas about self-concept formation, is the basis of the labeling theory of deviance, which proposes that a key factor in the development of deviants is the negative label of identity imposed on the person, (Becker 1963).

The importance of others in the formation of self-concepts is captured in Cooley's (1902) influential concept, the looking glass self. Cooley proposed that to some extent individuals sees themselves as they think others see them. Thus disabled in our society begin to see themselves as shame and not worthy to associate with non-disable, because of how people perceive and evaluate them, and they are motivated to act according to their conception of the identity and this affect their relationship with others. The research indicates that positive reflected appraisals from parents along with parental support and the use of inductive control have positive socialization outcomes for the children's self-concept (Gecas and Schwal be 1986, Peterson and Rollins 1987).

Symbolic interactions approach was criticized by many sociologists who argued that it is necessary to look at social structure in order to understand the complexity of relations through which the interactions are inter-connected but that symbolic interactions approach is without such focus and as such suffer from lack of Coherence (Ritzer 1996) also, the mainstream of symbolic interactionism has abandoned the practice of empirically based research techniques. Their concepts have not been developed into formal systematic theory. Many social theorists have argued that due to its subjective nature, the research product of symbolic interactionism has remained untested (Gouldner, 2000).

\section{Objective 1: Conceptualization, Rationale and Benefits of Inclusive Education in Society (Nigeria inclusive)}

Conceptualizing Inclusive Education This is a complex, if not a problematic concept. Despite the internationalization of the philosophy of inclusive education (UNESCO, 1994, 2008), for a range of historical, cultural, social and financial reasons, its implementation has been uneven across the world. Lipsky \& Gartner (1996, 1999), described inclusive education as students with disabilities having full membership in age-appropriate classes in their neighborhood schools, with appropriate 
INTERNATIONAL JOURNAL OF ACADEMIC RESEARCH IN BUSINESS AND SOCIAL SCIENCES Vol. 8, No. 9, Sept. 2018, E-ISSN: 2222-6990 @ 2018 HRMARS

supplementary aids and support services. To Antia et al., (2002), Inclusive education denotes a student with a disability unconditionally belonging to and having full membership of a regular classroom in a regular school and its community.

Earlier, skritic et al., (1996) had argued that inclusive education goes for beyond physical placement of student with disabilities in general classrooms, but should involve schools meeting the needs of all their students within common, but fluid, environments and activities. This broadened concept validation of inclusive education was recently articulated in the meeting at the forty-eight session of the UNESCO International Conference on Education, held in Geneva in November 2008, where it was acknowledged that inclusive education is an ongoing process aimed at offering quality education for all while respecting diversity and the different needs and abilities, characteristics and learning expectations of the students and communities, eliminating all forms of discrimination (UNESCO, 2009).

Rationale of Inclusive Education Advocacy for inclusive education revolves around three main arguments. Firstly, several writers' claims that inclusive education is a basic human right for example, Christensen (1996) argued that exclusion or segregation of students with special needs is a violation of their human rights and represents and unfair distribution of education resources. Similarly, Lispsky \& Gartner $(1996,1999)$ asserted that inclusive education is a fundamental right, derived from the principle of equity, which, if recognized would contribute significantly to a democratic society. This is also emphasized in UNESCO's Salamanca statement (1994) and by Slee (2001), the latter considering that inclusive education is about the cultural politics of protecting the rights of citizenship for all students. Oliver (1996) argued that the education system has failed disabled students by not equipping them to exercise their rights and responsibilities as citizens, while the special education system has functioned to exclude them from both the education process and wider social life.

Secondly, as Lipsky \& Gartner $(1996,1999)$ pointed out, in designing educational programmes for students with disabilities, the focus must shift from the individual's impairments to the social context, a key feature of, which should be a unitary education quality education for all students.

Third argument asserts that since there is no clear demarcation between the characteristics of students with and without disabilities and there is no support for the contention that specific categories of students learn differently, separate provisions for such students cannot be justified (Lipsky \& Gartner, 1996, 1999).

In relation to students with disability, the United Nations Educational, Scientific and cultural organization(UNESCO) first stated in 1994 that inclusive schools were the most effective way to counter discriminatory approaches and attitudes towards students. International legislation and policy subsequently evolved to challenge exclusionary practices and focus attention on equity and access to high-quality education for all, while respecting diversity (UNESCO, 2008). According to UNESCO (2009), an inclusive education system can only be created if ordinary schools become more inclusive, in other words, if they become better at educating all children in their communities. Article 24 of the unconventional on the rights of persons with disabilities recognizes that education should be accessible...without discrimination and on the basis of equal opportunity within an inclusive education system at all levels. It is widely acknowledged, nonetheless, that children with disability 
INTERNATIONAL JOURNAL OF ACADEMIC RESEARCH IN BUSINESS AND SOCIAL SCIENCES Vol. 8, No. 9, Sept. 2018, E-ISSN: 2222-6990 @ 2018 HRMARS

continue to experience different forms of exclusion which vary depending on their disability, domicile, and the culture or class to which they belong (UNICEF, 2013).

The principles of inclusive education for example were adopted at the Salamanica World Conference on special needs education. (UNESCO, 1994) and were restated at Dakar World Education Forum (2000). It reads:-

Inclusive education means that schools should accommodate all children regardless of their physical, intellectual, social, emotional linguistic or other conditions. This should includes disabled and gifted children, street and working children, children from remote or nomadic population, children linguistic ethic or cultural minorities and children from other disadvantage or marginalized areas or groups (UNESCO, 2003).

Some inclusive education scholars, such as Miltler (2012) and Ainscow and colleagues (see for example Aniscow,Dyson, Goldrick, \& West, 2011), conceptualize the task of inclusive education as being that which identifies and removes barriers to participation in education.

Finally, Loremaw (2009) defines inclusive education as follows:

- All children attend their neighbourhood school.

- All children learn in regular, heterogeneous classrooms with age peers.

- All children follow substantively similar programs of study, with curriculum that can be adapted and modified if needed. Modes of instruction are varied and responsive to the needs of all.

- All children are welcomed and valued

Benefits Derivable from Inclusive Education This strategy to education benefits all students. It ensures reasonable accommodations for all the children with disabilities. Inclusive education promotes the education of children with disabilities in general education programs.

Inclusive education benefit communities, families, teachers and students by providing knowledge and understanding of disability related issues. Inclusive education ensures children with disabilities attend school with their peers and teaches them life skills (C.R.S Victnam, 2008). Inclusion of children with disabilities in general schools introduce children with disabilities into local communities and neighborhoods and helps to break down barriers and prejudice communities become more accepting of differences, and everyone benefits from a friendlier, open environment (C.R.S Victom, 2008).

An analysis by Baker, Wang and Walberg in 1994 concluded that "special needs students educated in regular classes do better academically and socially than comparable students in non-inclusive settings". Research by Hollwood et al., (1995) found inclusive education was not detrimental to students without disabilities.

In May 2000, the Indiana inclusive study concluded that students without disabilities who were educated in inclusive settings made significantly greater progress in Math than their peers. And also students without disabilities can serve as positive speech and behavior role models and offer acceptance, tolerance, patience and friendship.

All children, with and without disabilities benefit from a teaching style catered to their individual way of learning. Inclusive education also features different teaching techniques such as drawing, singing, and participatory activities. Inclusive education also allows teachers to become more dynamic in their classroom, and thus makes school more enjoyable for children and teachers (C.R.S Victnam, 2008). 
Sheets and Wirkrus, outline the following benefits of inclusive education as follows:

- Increased self-motivation

- Increased independence

- Integrated and required participation

- Accountability

- Expanded learning and life experiences

- New opportunities for interactions and communication

- Changed vision of potential by adults, peers and child (Sheets and Wirkus, 1997, p.8).

Inclusive education removes barriers to participation and learning for all children. It helps to reduce poverty in many countries. It offers the disabled an opportunity to gain employment in firms, industries and in governmental departments. Also children with disabilities are less stigmatized, and also produce positive changes in attitudes within schools and in societies as well. It also leads to greater social cohesion.

Objective 2: Stakeholders in Inclusive Education in Nigeria and Categories of Children with Disability (CWD) who Require Inclusive Education in Nigerian Nation

Implementation of inclusive education policy is not a government affair alone. Indeed, to continually improve and achieve inclusive education, action is needed, beyond national government, to involve stakeholders at every level as follows

- For local authorities: The development of local policies for implementation of inclusive education, appropriate support for individual schools, provision of funding, securing the necessary building adaptations and the provision of resource centers.

- For individual school: The introduction of an inclusive educational environment which addresses the cultures, policies and practices of the school to ensure that the basic conditions exist in which all children can participate and learn.

- For parents: Sending all their children to school, and supporting them both in their education, and in helping to ensure that schools comply with the principles of an inclusive approach.

- For children: To take advantage of opportunities to participate and learn, support their peers and co-operate with the values of inclusive schooling.

- For civil society: Supporting the development of community based inclusive education and contributing to an environment of respect and acceptance.

\section{Categories of Children with Disability who Require Inclusive Education in Nigeria}

This concept of children with disability should be distinguished from the term "handicap" which is too often used synonymously with disability. To say that a person is handicapped is to mean that he is completely hopeless. But when we say that a person is disabled, it means that all is not lost. In other words, a disabled person can be helped to adjust to, or compensate for his disability while a handicapped person cannot be helped (see e.g. Ekeme, 1987, 3-4).

There are various types of disabilities which can be grouped into four broad categories, namely physical and health, hearing, visual and mental disabilities. Cripple, lame, physical handicap and 
delicate are", according to Ogbue, some of the terms often used to categorize a variety for conditions which limit the normal use of body and/or limbs| (Ogbue, 1987:95).

Persons with hearing and speech disabilities are commonly referred to as deaf and dumb respectively. Each of these disabilities can be classified into different categories for instance; there is a difference between persons who are deaf and those who are hard-of-hearing. "The hard-ofhearing" unlike the deaf are those who have difficulty in hearing loudly spoken speech but can hear amplified speech by means of a hearing aid" (Igbokwe, 1987: 19).

Persons with visual disability are usually referred to as blind, but blindness can be distinguished from low vision and partial sight. A blind person is one who "cannot read and write after all optical corrective measures have been taken" (Abosi 1987-121-122). Low vision and partial sight on the other hand refer respectively to persons.

a. "Who might have been certified blind but have some residual vision, or have limitations in distance vision" and,

b. "Whose sights, though poor, is not so bad that they can be regarded as blind". (Abosi 1987: 122).

Finally, mental disability has been defined from medical, social psychological and educationist perspectives (see e.g. Prins, 1980 42-44).

Objective 3: Disability Related Problems Encountered in Schools and the Nigerian Society at Large Three Unrecognized Sub-groups of Children There are at least three subgroups of children whose dual exceptionality remains unrecognized (Baum, Owen \& Dixon, Fox, Broady, \& Tobin, 1983, Landrum, 1989, Starnes, Ginevan, Stokes \& Barton, 1988). The first group includes students who have been identified as gifted yet exhibit difficulties in school. These students are often considered underachievers, and their underachievement may be attributed to poor self concept, lack of motivation, or even some less flattering characteristics, such as laziness (Silverman, 1989, Waldron, Saphire, \& Rosenblum, 1987, Whitmore, 1980). Their learning disabilities usually remain unrecognized for most of their educational lives.

A second group includes students whose learning disabilities are severe enough that they have been identified as having learning disabilities but whose exceptional abilities have never recognized or addressed. In his study, Baum (1985), found that as many as $33 \%$ of students identified with learning disabilities had superior intellectual ability. The researcher observed that inadequate assessments and/or depressed IQ scores often lead to an underestimation of these students' intellectual abilities. Perhaps the largest group of unsaved students are those whose abilities and disabilities mask each other, these, children sit in general classrooms, ineligible for service provided for students who are gifted or have learning disabilities, and are considered to have average abilities. When educators and researchers describe these students as a unique group, they generally talk about students who exhibit strengths in one area and weaknesses in another (example, Ellston, fall \& \Nolan, 1993) and/or show a discrepancy between potential and performance (example, Gunderson, Maeschi \& Rees, 1987). The main reason people with disabilities encounter hardship is because they suffer discrimination along the same lines as racial or ethnic minorities.

Accordingly, civil rights protections and anti-discrimination laws are the proper responses to disability (example, Hahn, 1997 and Oliver, 1990). Disability is "an extension of the variability in physical and 
INTERNATIONAL JOURNAL OF ACADEMIC RESEARCH IN BUSINESS AND SOCIAL SCIENCES Vol. 8, No. 9, Sept. 2018, E-ISSN: 2222-6990 @ 2018 HRMARS

mental attributes beyond the present but not the potential ability of social institutions to routinely respond" (Scotch and Schriner, 1997). This view of disabilities as human variations is closely related to the view that disability is a universal human condition (Zola, 1989) or shared human identity (Davis, 2002). The disability rights movement has long complained that the perspective of people with disabilities are too often ignored or discounted. The Slogan that served as the title for James Charlton's 1998 book, nothing about us without us (Charlton, 1998, Stone 1997) has often been invoked to demand the inclusion of people with disabilities in policy making and research concerning disability.

In conclusion, many non-disabled people assume that people with disabilities won't make good partner and cannot or should not become parents (Safilias-Rothsclid, 1970; Shakespeare, 1996; Asch and fine 1988, Wates 1997) people with disabilities are perceived to be globally helpless based on their need for a assistance with some facets of daily life (Wright, 1983), fueling the conviction that they are unable to render the help needed for successful partnership or parenting.

Stigmatization of Disabilities Merrian Webster Dictionary of (2014) defines stigma as a mark of shame or discredit. Stigma is often associated with discrimination and human rights violation and has been define in various ways. Goffman (1963), defines stigma as an undesirable or discrediting attribute that an individual possesses thus reducing the individual status in the eyes of the society. Stigma can stem from a particular characteristic, such as a physical deformity or form negative attitudes toward a group. Jones, Farina and Hastorf (1984) define stigma as an attribute that links a person to undesirable characteristics.

According to Cameron in Monjok (2009), Stigmatization can lead to prejudicial thoughts, behaviours and actions on the part of government communities, employers, health care providers, co-workers, friends and families. In the same vein, UNAIDS (2000), defined stigma as any form of exclusion or restriction of expression, marginalization or prevention from access to something or services. Stigma has been classified by several authors, some divide stigma into felt or perceived stigma and enacted stigma (Scraruble, 1998).

Okeke (1982) pointed out that the managers of commercial firms do not accept the handicapped or disabled persons. According to him, only the missionaries or the voluntary organizations can employ them for mercy, sake and not on the basis of production adding that their employment is humanitarian. Shoron (1980) contents that majority of Nigerian disabled are still being denied the opportunity to secure jobs in firms, industrial and in government departments.

In Europe and America, for example, it was only in 1800, long after the education of the able-bodies has been well established, that private schools and centers for the disabled person began to spring up. Prior to that period, however, the disabled persons were either destroyed or isolated or exploited for public entertainment or used as "Jesters" (Ekeleme, 1978:10). In Nigeria too, many communities in the past used to hold strongly to the view that disability/handicap is a punishment for sin committed either by the disabled himself or his parents. As a result such Nigerians did not sympathize much less empathize with the disabled person (Obani, 1984).

Ogbue et al., (1987) in their book observed that the belief of avoiding whatever is associated with evil has from history affected peoples attitude towards the disabled. This is because disability conditions were originally associated with evil. 
INTERNATIONAL JOURNAL OF ACADEMIC RESEARCH IN BUSINESS AND SOCIAL SCIENCES Vol. 8, No. 9, Sept. 2018, E-ISSN: 2222-6990 @ 2018 HRMARS

Finally, Shertzer and Stone (1981) opined that disabled individuals should be granted placement in appropriate occupations. For them, individuals with disabilities like arm and leg deformities, amputations, defects of hearing, or speech and vision are eligible for services and should not be stigmatized.

\section{Objective 4: Fundamentality of Right to Education, Access to Health Information and Educational Support for all Children in Nigeria}

Every child has the right to education. This is according to Article 26, Section One of the Universal Declaration of Rights; Everyone including the thousands of physical challenged children who roam the streets of Nigeria in search of alms; Everyone-blind, deaf or Autistic.

The transformative inclusive agenda is based on the assertion of the same right to a quality education with their communities for all learners. Thus it can be seen to concur with task of Education for All (UNESCO, 1999).

Inclusive educational practices are being endorsed internationally. The UNESCO sponsored education for all initiative states that all children, including those with disabilities and special needs, are entitled to equity of educational opportunity. UNESCO and the OECD have also determined that Inclusive Education is the preferred approach to providing schooling for students with special needs.

Educational policies at all levels, from national to the local, should stipulate that a child with a disability should attend the neighborhood school that is the school that would be attended if the child did not have a disability p. 17, (UNESCO, 1994). (Article 18, Salamanca statement) at the subsequent $28^{\text {th }}$ session of the UNESCO General Conference ( $28 \mathrm{C}$ resolution 1.5 ) member countries were called on to follow up on the recommendations of the Salamanca World conference on special needs Education and to reorient their educational strategies to meet special educational needs within the mainstream, as well as work towards inclusive education.

In 1999 the organization for Economic Cooperation for Economic and Development (OECD) completed and extensive study of special education practice in eight member countries. The OECD report concludes that on the basis of the results of this study (OECD, 1999).

Finally, there is no reason to segregated disabled students in public education systems; instead education systems need to be reconsidered to meet the educational needs of all students. To ensure social well-being for all people, societies have to be based on justice, equality, equity inclusion and interdependence, and recognize and accept diversity societies must also consider their members, above all, as persons, and assure their dignity, rights, self-determination, full access to social resources and the opportunity to contribute to community life (Cad, 1993).

On the other hand, health information dissemination refers to all processes aimed at educating, enlightening, informing or transmitting to the people, health issues that are of benefit to them. It is intended to improve health information at their disposal such that they can live much healthier lives, shaped by informed choices they make. Such choices are derived or anchored on correct health information at their disposal. The concepts of health education and health information dissemination are for purposes of this paper considered as interchangeable terms with complimentary meanings and objectives. Such health information is also considered as rights which are better harvested if one is educated via the inclusive strategy. 
INTERNATIONAL JOURNAL OF ACADEMIC RESEARCH IN BUSINESS AND SOCIAL SCIENCES

Vol. 8, No. 9, Sept. 2018, E-ISSN: 2222-6990 @ 2018 HRMARS

\section{Discussion of Results and Policy Implications/ Key Features that will contribute to the Success of Inclusive Education in Nigeria}

The overall stand of this review paper is that the implementation of inclusive education is yet to attain appreciable heights in Nigeria; successes are minimal compared to several operations problems. The literature reviewed attest to this stand. Stakeholders are yet to adhere and discharge their roles; capacity of teachers is still very deficient, while parents are poorly sensitized about the meaning and their crucial roles in the inclusive education project. All these may explain why special schools for children with disabilities still dominate in Nigeria rather than the anticipated massive shift to inclusive education option that will bring such children under same instructors and schools to access education and health information together with counterparts without disability.

Against the backdrop of poor performance of Nigeria's inclusive education programme, the understated key features that could contribute to the success of inclusive education are advocated. According to Winter and O, Raw (2010), these keys include:

- Leadership: Research consistently demonstrates that with effective leadership for inclusive education, success will be difficult to achieve. Leaders must be knowledgeable supporter of inclusion who provides caring support for their stuff (Hoppcy and Mcleskey, Jones Forlin, \& Gillies, 2013).

- Teachers: must accept ownership of the process and a commitment to all children in a class. In addition, teachers must be highly skilled practitioners (Florian, 2012, Smith \& Tyler, 2011).

- Teacher's beliefs and attitudes: Positive attitudes must be evident if inclusive education is to be successful and teachers must believe that all students are capable of learning and contributing to the classroom community in positive ways (Jordan, Glenn an Mcahie-Richmond, 2010, Sharma, 2012).

- Teacher training: A high degree of teacher efficacy for inclusive practice must be provided and teacher must take ownership over their learning and seek out opportunities for professional growth (Piji, 2010, Smith and Tyler, 2011).

- Teacher needs: These can include planning time, training, personnel resources, material resources, class size, and consideration of the severity of the disability (Eisenman, pleet, Wandry and Mcginley, 2011).

- Teaching assistants: Trained and knowledgeable teaching assistants are very helpful in facilitating inclusive education, as they work under the direction of classroom teacher (symes and Humphrey, 2011).

- Family involvement: The involvement of the family is an important and essential element in the success of inclusive education. True home school collaboration is necessary for success (Stivers, Francis Cropper, and Stravs, 2008).

- The voice of the child: The involvement and active engagement of the child is an essential part of the process. Education is no longer something done to children, but a process that children own and should actively participate in (Mession 2012). And finally,

- Curriculum: Flexible curriculum and the use of individualized instruction and plans are important elements of a successful inclusive education program (Osberg and Biesta, 2010).

Ways through which Provision of Inclusive Education could be improved in Nigeria

Inclusive education can be improved through the following:- 
INTERNATIONAL JOURNAL OF ACADEMIC RESEARCH IN BUSINESS AND SOCIAL SCIENCES

Vol. 8, No. 9, Sept. 2018, E-ISSN: 2222-6990 @ 2018 HRMARS

- Emphasizing the value of building positive schools and their values and surrounding communities.

- Improving schools for staff and parents as well as children.

- Developing cultures, policies and practices promote diversity and respect of everyone equally.

- Learning from inclusive practice to share the lessons widely.

- Putting inclusive values into action

- Valuing everyone life equally.

- Fostering positive relationships between schools and their values and surrounding communities.

- Promoting children participation in learning and teaching.

- Reducing exclusion, discrimination and barriers to learning and participation.

- Fulfilling the right to education for example, by ensuring that quality education is available for all children, promoting inclusive education, and introducing positive measures to enable children to benefit from it, for example, making physical adaptations to buildings, proving accessible transport, adapting the curricula to the needs of all children and proving necessary equipment and resources.

- To protect the right to education for example, by taking the necessary measures to remove the barriers to education posed by individuals or communities, for example, resistance by teachers to accepting children with disabilities, or violence, abuse or bullying in the school environment. The 1994 Salamanca statement calls on government to:

- Develop demonstration projects and encourage exchanges with countries having experience with inclusive schools.

- Establish decentralized and participatory mechanism for planning, monitoring and evaluating educational provision children and adults with special education needs.

- Gives the highest policy and budgetary priority to improve their education systems to enable them to include all children regardless of their individual differences or difficulties.

- Ensure that, in the context of a systemic change, teacher education programme, both preservice and in-service, address the provision of special needs education in inclusive schools.

\section{Conclusion}

Literature reviewed in this study indicates that educational support for children with disabilities improves their academic performance. Also, the study noted that the disabled persons are stigmatized by the public. Several factors such as teacher's belief and attitudes, teacher training; leadership and so on influence the success of Inclusive education. Also several factors such as parental style, method of teaching and parental socio economic status were noted to improve pupil's academic performance. Above all, inclusive education benefits all pupils, schools, families and so on. It also promotes the education of children with disabilities in general education programs.

There is no best practice model of inclusive education and there are many countries that have not properly attended to the education of children with disabilities; so there is a great deal of progress 
to be made in fulfilling the obligation of inclusive education for children with disabilities in the Nigerian environment.

Inclusive education in most of the developing countries like Nigeria still remains in the realm of theory and far from practice; it is still grappling with problems of policy implementation, and environment that is not conducive for practice. Also children with disabilities remain marginalized in parts of Nigeria, with their right to education and access to health information far from being fully realized. Although significant efforts have been made to overcome such discrimination and exclusion, too often such measures are poorly implemented. It is hoped that with inclusive education, equalizing educational opportunities for all children will be fully achieved in Nigeria.

\section{Contribution to Knowledge}

The theoretical and contextual contribution of this review paper to knowledge is appreciated from its comprehensive analysis of inclusive education efforts in Nigeria anchored on symbolic interactionism theoretical platform. It decried the implementation challenges faced by inclusive education in Nigeria. In particular, unlike other works that viewed inclusive education narrowly as an educational approach to assist children with disability in their learning effort, the current study strongly stressed the role of inclusion as a means of broad national economic advancement. Above all, this review uniquely linked level of access to health information on the part of children with disability to the extent to which inclusive education is successful. This is because all beneficial information or knowledge (including health information) is best transmitted and internalized under inclusive education setting.

\section{Recommendations}

Based on facts from literature consulted in this study, the following recommendations are made.

1. Ministry of education should also intensify in their efforts in bringing education for all. Inclusive education as a strategy to attain education for all should be adequately supported and financed. It is the duty of the government, schools and other international organizations to provide funds and promote incentives for inclusive education.

2. Parental education programmes should be provided to parents to support their children's learning, for example through parent -to-parent counseling, mother-child or civil society outreach through house to house visits.

3. Inclusive learning environment should be created through engagement of teacher's associations', school boards, parent teacher associations and other functioning school support groups with programmes to increased their understanding and knowledge of disability.

4. Segregation within schools should stop forthwith through legislation and by monitoring schools on a regular basis to stamp out segregation operating formally or informally.

\section{References}

Abosi, C. O (1987), "Usual Impairment" in Ogbue, R. M and Obani; T. C. (eds), Special Education: A reading Text, (Heineman Educational Books Nigeria PLC)

Ainscow, M., Oyson, A. Goldrick, S. \& West M. (2011). Developing equitable education system. Abingdon, Uk: Rutledge. 
INTERNATIONAL JOURNAL OF ACADEMIC RESEARCH IN BUSINESS AND SOCIAL SCIENCES

Vol. 8, No. 9, Sept. 2018, E-ISSN: 2222-6990 @ 2018 HRMARS

Cooley, R. J. (2002). An uneven start: Indicators of inequalities in schools' readiness. Princetown, Educational Testing Service.

Eisenman. L. T., Pleet, A. M., Wandry, D., \& McGinley, V. (2011). Voices of special education teachers in Inclusive High School: Redefining responsibilities. Remedial and special Education, 32(2), 91-104)

Florian, L. (2012) preparing teachers to work in Inclusive classroom: key lessons for the professional development of teacher educators from Scotland's Inclusive practice product. Journal of Teacher Education, 63(4), 275-285.

Forlin, C. (2013a). Issues of Inclusive Education I the $21^{\text {st }}$ Century. Journal of learning science No.6, 67-81

Goffman, E. (1963). Stigma notes on the management of spoiled identify. New York Simon and Shuster Inc

Hoppey, D. \& Mcleskey, J. (2013). A ease study of principal leadership in an effective inclusive school. Journal of Special Education, 46(4), 245-256.

Heslon, R. (1972). Non Verbal Behaviour and Social Psychology. New York: plenum Books.

Haralambus, M. and Holborn, M. (2004). Themes and perspectives (5 $5^{\text {th }}$ edition) London: Collins Educational Books.

Jordan, A. Glenn, C., \& McGhie-Richmond, D. (2010). The supporting Effective Teaching (SET) project: The relationship of inclusive teaching practices to teachers beliefs about disability and ability and about their roles as teachers. Teaching \& Teacher Education, 26(2), 259-266. Dol: 10.10(6/j) tate 2009.03.05

Jones, P., Forlin, C., \& Gillies, A. (2013). The contribution of facilitated leadership to systems development for greater inclusive practices. International journal of whole schooling, 9(1) online at http://www.whoileschoolingnet/jounrnalofwholeschooling/ijwsi dexhtml

Loreman, T. (2009).Straight talk about inclusive education. CASS connections, spring.

LAEYC (1991). Accreditation criteria and procedures of the National Academy of Early childhood program. Washington, DC International Association for the Education of Young children (LAEYC).

Mittler, P. (2012). Overcoming exclusion: Social Justice through education. Abbingdon, Uk: Routledge.

Messiou, K. (2012). Collaborating with children in exploring marginalization an approach to inclusive education. International Journal of Inclusive Education, 16 (12), 1311-1322. Doi:10.1080/13603116. 2011.52188.

Monjok, E. (2009). HIV/AIDS related stigma and discrimination in Nigeria: Review of research studies and future directions for preventions. African Journal if reproductive Health, 13 93) 21-35.

Oakes, J \& Saunders, M. (2002). Access to textbooks, Instructional Materials, Equipment, and Technology Inadequacy and Inequality in California's public schools los Angeles UCLA's Institute for Democracy, Education, and Access.

Ogbue, R.M 91987), "Physical and Health Impairment" In R.M Ogbue and T.C Obani (eds.), special Education (Heineriann Educational Books Nigeria Plc). 
INTERNATIONAL JOURNAL OF ACADEMIC RESEARCH IN BUSINESS AND SOCIAL SCIENCES

Vol. 8, No. 9, Sept. 2018, E-ISSN: 2222-6990 @ 2018 HRMARS

Osberg, D., Biesta, G. (2010). The end/s of education: Complexity and the conundrum of the Inclusive educational curriculum. International Journal of Inclusive Education, 1496), 593-607.

Piji, (2010). Preparing teaching for Inclusive education: Some reflections from the Netherlands Journal of Research in special Education Needs, 10/10 197-201 doi-10uu/j 1471-3802 2010. 01165.

Smith, D. \& Tyler N. (2011). Effective Inclusive education: Equipping education professionals with necessary skills and knowledge. Prospects, 41930, 323-339. Doi:10.1007/511125-011-92075.

Stivers, J., Francis -Cropper, L. \& Staw, M. (2008). Educating families about inclusive education. 2 month -by- month guide for teachers of inclusive classes. Intervention in school and clinic, 44(1), 10-17

Symes, W., \& Humphrey, N. (20110. The development, training and teacher relationships of teaching assistants supporting pupils with autistic spectrum disorders (ASD) in mainstream secondary schools. British Journal of special Education, 38 92) 57-64. Doi 10.111/j 1467.8578.2011.00499.x.

Stone, K. G. 1997, Awakening to Disability: Nothing about US without US, Vol cow, CA: Volcano press. Sheets, Lana and Wirkus, Mary (19970. Everyone's classroom: An environment designed to invite and facilitate active participation closing the Gap, volume 16- Number 1, 1-9.

UNESCO (2009). Policy guidelines on Inclusion in education. Retrieved 23 May, 2013, from http//www: inclusive-education-in-action org/iea/dokumente/upload/72074-177849 e.pdf.

UNESCO (2012). Education: Addressing exclusion. Retrieved from: http//www.unesco.org/new/en/education/themes/strengtheiing-educationsystems/inclusive-education.

UNESCO (2008). Inclusive education: the way of the future. Conclusions and recommendations of the $48^{\text {th }}$ session of the International conference on education (ICE) Geneva 25-28 November, 2008 Retrieved from. www. Ibeunesco.org/National-Reports//ce-2008/brazil-November, 2008. Retrieved from www.ibeunesco.org/National -Reports//CE 2008/brazil-NR08 pdf

UNICEF (2013, May). The state of the world's children children with disability. Retrieved from: http//www. Unicef.org/publications/files/SWCR 2013-ENG-LO-RES-24-Apr- 2013 pdf.

Winter, E., \& O. Raw, P. (2010). Literature Review of the Principles and practices relating to inclusive education for children with special educational needs. Trim,/reland: National council for special Education.

Davis, L.J., (2002). Bending over Backwards: Disability, Dis modernism \& other difficult positions, New York University press.

Centre for Disease control and prevention (2010). Association between school-based physical activity and academic performance. Retrieved from http://ede.gov/healty/youth/healthandacademics.

Ezeah, P.C. \&/Ffih, B.C. (2004). Sociology of the family. Enugu Nigeria. John Jacobs classic publisher Ltd.

Egbue, N. (2010). Sociology of Education Lecture Note: Sociology Department Unizik Awka.

Ekeleme, R. (1987), Introduction and concepts of special Educational Books Nigeria PLC). 
INTERNATIONAL JOURNAL OF ACADEMIC RESEARCH IN BUSINESS AND SOCIAL SCIENCES

Vol. 8, No. 9, Sept. 2018, E-ISSN: 2222-6990 @ 2018 HRMARS

Igbokwe, K. (1987), "Hearing Impairment" in Ogbue, R.M and T.C Obani (eds) special Education, Heinemann Educational Books Nigeria PLC).

Ritzer, G. (1996). Modern Sociological theory. New York. MC Graw-Hill.

Rossides, D.W (1978). The History and Nature or sociological theory. Boston. Houghton Mifflin Company. 